Рекомендована д. хім. наук, профр. В. С. Матійчуком

УДК 615.012.1:547.789.1

DOI 10.11603/2312-0967.2017.1.7533

\title{
СИНТЕЗ 3-ПІРИДИЛЗАМІЩЕНИХ 4-ТІАЗОЛІДИНОНІВ ЯК ПОТЕНЦІЙНИХ БІОЛОГІЧНО АКТИВНИХ СПОЛУК
}

\author{
() М. Н. Войтира, Р. Б. Лесик \\ Львівський національний медичний університет імені Данила Галицького \\ madzia_ustka@interia.pl,dr_r_lesyk@org.lviv.net
}

\begin{abstract}
Мета роботи. Здійснити синтез 3-піридилзаміщених 5-ариліден-4-тіазолідинонів потенційних біологічно активних сполук.

Матеріали і методи. Вихідні реагенти синтезовані за відомими методиками із комерційно доступних реактивів. ${ }^{1} \mathrm{H}$ ЯMP спектри знімались на приладі Varian Gemini $400 \mathrm{MHz}$. Температури плавлення визначали на приладі BÜCHI B-545.

Результати й обговорення. Одержано 3-піридилзаміщені 5-ариліден-2-тіоксо-4-тіазолідинони на основі методу Гольмберга та реакції Кньовенагеля. Для синтезу структурно подібних 3-(2-піридил)-2,4-тіазолідиндіонів запропоновано двохетапний підхід, який базується на однореакторній («one-pot») трикомпонентній реакції 1-бензоїл-3-(піридин-2-іл)-2-тіосечовини, монохлороцтової кислоти та ароматичного альдегіду 3 утворенням 5-ариліден-2-бензоїліміно-3-(2-піридил)-4-тіазолідинонів, які при кислотному гідролізі 3 високими виходами утворюють цільові продукти. Структура синтезованих сполук підтверджена методом спектроскопії ПМР.

Висновки. Синтезовано серію нових 3-піридилзаміщених похідних роданіну, тіазолідиндіону і псевдотіогідантоїну. Стереоселективність реакції Кньовенагеля і утворення 5-(Z)-ариліден-4-тіазолідинонів підтверждено даними спектрів ПМР.
\end{abstract}

Ключові слова: синтез; 4-тіазолідинони; [2+3]-циклоконденсація; реакція Кньовенагеля; спектральні характеристики.

Вступ. Поєднання 4-тіазолідинонового і піридинового фррагментів у одній молекулі є ефективним підходом до дизайну потенційних «лікоподібних молекул». На сьогодні важливим завданням медичної хімії є створення есрективних та низькотоксичних лікарських засобів. Одним із вирішень цієї проблеми є концепція «гібрид-фрармакофорного підходу», яка полягає в поєднанні різнопланових «структурних матриць» в одній молекулі з метою досягнення біосинергізму. Такий підхід досить часто приводить до нового фрармакологічного профрілю, потенціювання дії та зниження токсичності «гібридних» молекул $[1,2]$. У своїх дослідженнях як «структурні матриці» для дизайну нових «гібридних молекул» ми обрали гетероциклічні фррагменти 4-тіазолідинону та піридину. У сучасній медичній хімії похідні 4-тіазолідинону та піридину відомі суттєвим фрармакологічним потенціалом, в тому числі гіпоглікемічною, протираковою, протизапальною, протимікробною, противірусною, протисудомною та іншими видами активності [3-10].

Методи дослідження. При виконанні експериментальної частини роботи використані традиційні методи органічного синтезу. Вихідні реагенти синтезовані за відомими методиками із комерційно доступних реактивів. ${ }^{1} \mathrm{H}$ ЯМР спектри знімались на приладі Varian Gemini 400 MHz, використовуючи тетраметил- силан (TMC) як внутрішній стандарт та DMSO-d 6 як розчинник. Температури плавлення визначали на приладі BÜСН B-545. Чистоту та індивідуальність одержаних сполук підтверджено методом тонковерствової хроматограсрії (пластинки Merck, покриті silica gel 60 F254, елюент - суміш бензин - етилацетат 2:1). Дані елементного аналізу на вміст нітрогену і сульсуру відповідають розрахованим $( \pm 0,3 \%)$.

Результати й обговорення. 3 метою синтезу 3-піридилзаміщених 2-тіоксо-4-тіазолідинонів (роданінів) обрано метод Гольмберга, який базується на взаємодії тіокарбоніл-біс-тіогліколевої кислоти з відповідними амінами. Тіокарбоніл-біс-тіогліколеву кислоту одержано взаємодією тритіокарбонату натрію, як іn situ інтермедіата, і монохлороацетату натрію за методикою, запропонованою нами раніше [11]. Як аміно компоненту реакції використано 3-амінопіридин. Відомо, що наведена вище реакція проходить як «однореакторна» [2+3]-циклоконденсація і включає стадії амінолізу та гетероциклізації, що закономірно привело до утворення відповідного 3-(3-піридил)-2тіоксо-4-тіазолідинону 1 . Похідне роданіну $1 \in$ метиленактивним гетероциклом, що дозволило синтезувати 5-арилідензаміщені 2-6 в реакції Кньовенагеля (середовище - оцтова кислота, каталізатор - ацетат натрію) з деякими ароматичними альдегідами.

ISSN 2312-0967. Pharmaceutical review. 2017. № 1 
Синтез біологічно активних сполук

Synthesis of biologically active compounds<smiles>O=C(O)CCC(=S)SCC(=O)O</smiles>

1. $\mathrm{ClCH}_{2} \mathrm{COONa}$

2. $\mathrm{HCl}$

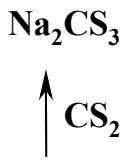

$\mathrm{Na}_{2} \mathrm{~S}$

2. $\mathrm{R}=2-\mathrm{F}$

3. $\mathrm{R}=4-\mathrm{Cl}$

4. $\mathrm{R}=4-\mathrm{Br}$

5. $\mathrm{R}=3,4-(\mathrm{OMe})_{2}$

Для синтезу структурно подібних 3-(2-піридил)-2,4тіазолідиндіонів запропоновано двохетапний підхід, який базується на використанні 1-бензоїл-3-(піридин-2іл)-2-тіосечовини, яку одержано за відомим методом на основі 2-амінопіридину [12]. Встановлено, що в однореакторній («оne-pot») трикомпонентній реакції тіосечовини, монохлороцтової кислоти та ароматичного альдегіду, яка включає послідовне проходження [2+3]-циклоконденсації і реакції Кньовенагеля, з задовільними виходами одержано 5-ариліден-2-бензоїліміно-3-(2піридил)-4-тіазолідинони 6-10. Зазначені сполуки легко гідролізують під дією хлоридної кислоти до цільових похідних 2,4-тіазолідиндіону 11-15.<smiles>N#C[C@@H](N)C(=O)NC(=S)Nc1ccccn1</smiles>

6, $11 \quad \mathrm{R}=4-i-\mathrm{Pr}$

$7,12 \mathrm{R}=4-\mathrm{OMe}$

$\mathbf{8 , 1 3} \mathrm{R}=3,4-(\mathrm{OMe})_{2}$

9, $14 \mathrm{R}=4-\mathrm{Cl}$

$10,15 \mathrm{R}=4-\mathrm{Br}$

Обґрунтуванням наведеного фррагменту досліджень, як і вибір оксосполук для фрормування 5-іліденового фррагмента, стали проведені нами поглиблені дослідження 5-іліден-4-тіазолідинонів, зокрема попередні висновки про критичний вплив іліденового

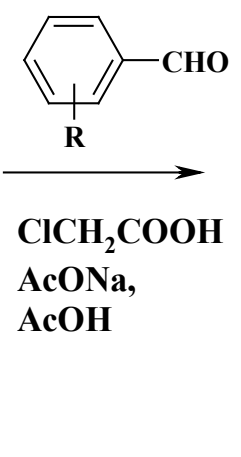<smiles></smiles>

\section{Експериментальна частина}

Синтез 3-(3-піридил)-2-тіоксо-4-тіазолідинону (1).

Суміш 0,05 моль 3-амінопіридину та тіокарбонілбіс-тіогліколевої кислоти в 20 мл етанолу нагрівають протягом 5 год у круглодонній колбі зі зворотним хо-

ISSN 2312-0967. Фармацевтичний часопис. 2017. № 1 
лодильником. Після завершення реакції суміш охолоджують. Осад, який утворився, відфрільтровують та перекристалізовують із етанолу. Вихід - 52 \%, Т.пл. - 164-165 º (EtOH). Знайдено, \%: N - 13.10, S 30.40. $\mathrm{C}_{8} \mathrm{H}_{6} \mathrm{~N}_{2} \mathrm{OS}_{2}$. Вирахувано, \% N-13.32, S - 30.50 . Спектр ${ }^{1} \mathrm{H}$ ЯМР, $\delta$, м.ч.: 4.50 с $\left(2 \mathrm{H}, \mathrm{CH}_{2}\right), 7.67$ дд $(1 \mathrm{H}$, $\mathrm{J}=4.7,7.8$ Гц, піридин), 7.86 д (1H, $\mathrm{J}=6.8$ Гц, піридин), 8.57 с (1Н, піридин), 8.75 д (1Н, J = 4.4 Гц, піридин).

Загальна методика синтезу 5-ариліден-3-(3піридил)-2-тіоксо-4-тіазолідинонів (2-5).

Суміш 0,0015 моль 3-(3-піридил)-2-тіоксо-4тіазолідинону 1, 0,0015 моль відповідного ароматичного альдегіду і 0,0015 моль безводного ацетату натрію в 8 мл оцтової кислоти кип'ятять із зворотним холодильником протягом 3 годин. Утворений осад відфрільтровують, промивають оцтовою кислотою, водою та етанолом і перекристалізовують 3 оцтової кислоти.

5-(Z)-(2-Фторобензиліден)-3-(3-піридил)-2тіоксо-4-тіазолідинон (2). Вихід - 95 \%, Т.пл. 153$155{ }^{\circ} \mathrm{C}$ (ЕtOH). Знайдено, \%: N - 8.90, S - 20.40. $\mathrm{C}_{15} \mathrm{H}_{9} \mathrm{FN}_{2} \mathrm{OS}_{2}$. Вирахувано, \% N - 8.85, S - 20.27. Спектр ${ }^{1} \mathrm{H}$ ЯМР, $\delta$, м.ч.: 7.45 м (3Н, аром.), 7.64 м (2H, піридин, аром.), 7.83 с (1Н, CH), 7.95 д (1Н, J =7.9 Гц, піридин), 8.66 с (1Н, піридин), 8.71 д (1Н, J =4.3 Гц, піридин).

5-(Z)-(4-Хлоробензиліден)- 3-(3-піридил)-2тіоксо-4-тіазолідинон (3). Вихід - 83 \%, Т.пл. 208$210{ }^{\circ} \mathrm{C}$ (EtOH). Знайдено, \%: N - 8.50, S - 19.30. $\mathrm{C}_{15} \mathrm{H}_{9} \mathrm{ClN}_{2} \mathrm{OS}_{2}$. Вирахувано, \% N - 8.42, S - 19.27. Спектр ${ }^{1} \mathrm{H}$ ЯМР, $\delta$, м.ч.: 7.60-7.63 м (5H, піридин, аром.), 7.85 с (1Н, CH), 7.90 д (1Н, J =7.9 Гц, піридин), 8.60 с (1Н, піридин), 8.66 дд (1Н, J = 1.4, 4.8 Гц, піридин).

5-(Z)-(4-Бромобензиліден)-3-(3-піридил)-2тіоксо-4-тіазолідинон (4). Вихід - 67 \%, Т.пл. - 210$212{ }^{\circ} \mathrm{C}$ (EtOH). Знайдено, \%: N - 7.50 S - 17.20. $\mathrm{C}_{15} \mathrm{H}_{9} \mathrm{BrN}_{2} \mathrm{OS}_{2}$. Вирахувано, \% N - 7.43 S - 17.00. Спектр ${ }^{1} \mathrm{H}$ ЯМР, $\delta$, м.ч.: 7.63 т (1Н, J = 8.7 Гц, піридин), 7.66 д (2H, J = 8.4 Гц, аром.), 7.80 д (2H, J = 8.4 Гц, аром.), 7.94 д (1Н, J = 8.2 Гц, піридин), 7.87 с $(1 \mathrm{H}, \mathrm{CH})$, 8.65 с (1Н, піридин), 8,70 д (1Н, J = 4.7 Гц, піридин).

5-(Z)-(3,4-Диметоксибензиліден)-3-(3-піридил)2-тіоксо-4-тіазолідинон (5). Вихід - 60 \%, Т.пл. 226-228 ${ }^{\circ} \mathrm{C}(\mathrm{EtOH})$. Знайдено, \%: N - 8.00, S - 18.00. $\mathrm{C}_{17} \mathrm{H}_{14} \mathrm{~N}_{2} \mathrm{O}_{3} \mathrm{~S}_{2}$. Вирахувано, \% N - 7.82, $\mathrm{S}-17.89$. Спектр ${ }^{1} \mathrm{H}$ ЯМР, $\delta$, м.ч.: 3.85 с $\left(3 \mathrm{H}, \mathrm{OCH}_{3}\right), 3.86 \mathrm{c}$ $\left(3 \mathrm{H}, \mathrm{OCH}_{3}\right), 7,19$ д $(1 \mathrm{H}, \mathrm{J}=8.1$ Гц, аром.), 7,31 м (2H, аром.), 7,64 т (1H, J = 7.6 Гц, піридин ), 7,85 с $(1 \mathrm{H}, \mathrm{CH}), 7,94$ д $(1 \mathrm{H}, \mathrm{J}=7.8$ Гц, піридин $), 8,65$ с (1Н, піридин), 8.71 д (1Н, J = 4.4 Гц, піридин).

Загальна методика синтезу 5-ариліден-2бензоїліміно-3-(2-піридил)-4-тіазолідинонів (6-10).

Суміш 0,01 моль бензоїлхлориду додавали протягом 5 хв до свіжоприготовленого розчину тіоціанату амонію (0012 моль) в сухому ацетоні. Одержану су- міш нагрівали зі зворотним холодильником протягом 15 хв. Нагрівання припиняли і додавали 2-амінопіридин в ацетоні протягом 15 хв. Суміш нагрівають із зворотним холодильником протягом 30 хв, а потім виливають на подрібнений лід. Одержаний осад відфрільтровують, промивають водою, висушують і без додаткової очистки використовують в наступних реакціях.

Суміш 0,003 моль одержаної бензоїлтіосечовини, 0,003 моль відповідного ароматичного альдегіду і 0,0015 моль безводного ацетату натрію в 5 мл оцтової кислоти кип'ятять із зворотним холодильником протягом 2 год. Утворений осад відфрільтровують, промивають водою, етанолом і перекристалізовують з етанолу.

5-(Z)-(4-Ізопропілбензиліден)-2-бензоїліміно-3(2-піридил)-4-тіазолідинон (6). Вихід - 58 \%, Т.пл. - 215-217 ${ }^{\circ} \mathrm{C}$ (EtOH). Знайдено, \%: N - 9,90, S - 7,70. $\mathrm{C}_{25} \mathrm{H}_{21} \mathrm{~N}_{3} \mathrm{O}_{2} \mathrm{~S}$. Вирахувано, \% N-9,83, $\mathrm{S}-7,50$. Спектр ${ }^{1} \mathrm{H}$ ЯМР, $\delta$, м.ч.: 1.25 д $\left(1 \mathrm{H}, \mathrm{J}=6.8\right.$ Гц, $\left.2^{\star} \mathrm{CH}_{3}\right), 2.99$ м $(1 \mathrm{H}, \mathrm{CH}), 7.47$ т $(2 \mathrm{H}, \mathrm{J}=7.4$ Гц, аром. $), 7.52$ д $(2 \mathrm{H}$, $\mathrm{J}=7.8$ Гц, аром.), $7.61 \mathrm{~T}(1 \mathrm{H}, \mathrm{J}=7.1$ Гц, аром.), $7.67 \mathrm{~T}$ (1Н, J = 5.2 Гц, піридин), 7.73 д (2H, J = 7.8 Гц, аром.), 7.76 д (1Н, J =7.8 Гц, піридин), 7.87 д $(2 \mathrm{H}, \mathrm{J}=7.7$ Гц, аром.), 7.99 с $(1 \mathrm{H}, \mathrm{CH}), 8.17 \mathrm{~T}(1 \mathrm{H}, \mathrm{J}=7.4$ Гц, піридин), 8.70 (1Н, J = 4.1 Гц, піридин).

5-(Z)-(4-Метоксибензиліден)-2-бензоїліміно-3(2-піридил)-4-тіазолідинон (7). Вихід - 80 \%, Т.пл. - 232-234 ${ }^{\circ} \mathrm{C}$ (ЕtOH). Знайдено, \%: N - 10,30, S 7,90. $\mathrm{C}_{23} \mathrm{H}_{17} \mathrm{~N}_{3} \mathrm{O}_{3} \mathrm{~S}$. Вирахувано, \% N - 10,11, S - 7,72. Спектр ${ }^{1} \mathrm{H}$ ЯМР, $\delta$, м.4.: 3.85 с $\left(3 \mathrm{H}, \mathrm{OCH}_{3}\right), 7.37 \mathrm{~T}$ (1Н, J = 7.6 Гц, аром.), 7.46 м (2H, піридин), 7.64 т (2H, J = 7.2 Гц, аром.), 7.75 д ( $2 \mathrm{H}, \mathrm{J}=8.4$ Гц, аром.), 7.84 д ( $2 \mathrm{H}, \mathrm{J}=8.4$ Гц, аром.), 7.88 д (2H, J = 7.6 Гц, аром.), 7.94 с $(1 \mathrm{H}, \mathrm{CH}), 8.15 \mathrm{~T}(1 \mathrm{H}, \mathrm{J}=7.4$ Гц, піридин), 8.70 д (1Н, J = 4.1 Гц, піридин).

5 - ( $Z$ ) - ( 3, 4 - Д и м е т о к и б е н з и л і д н ) - 2 бензоїліміно-3-(2-піридил)-4-тіазолідинон (8). Вихід - $62 \%$, Т.пл. - 208-210 ${ }^{\circ} \mathrm{C}(\mathrm{EtOH})$. Знайдено, \%: $\mathrm{N}-9,60, \mathrm{~S}-7,30 . \mathrm{C}_{24} \mathrm{H}_{19} \mathrm{~N}_{3} \mathrm{O}_{4} \mathrm{~S}$. Вирахувано, \% $\mathrm{N}-9,43, \mathrm{~S}-7,20$. Спектр ${ }^{1} \mathrm{H}$ ЯМР, $\delta$, м.4.: $3.84 \mathrm{C}$ $\left(3 \mathrm{H}, \mathrm{OCH}_{3}\right), 3.87$ с $\left(3 \mathrm{H}, \mathrm{OCH}_{3}\right), 7.12$ д $(1 \mathrm{H}, \mathrm{J}=8.1$ Гц, аром.), $7.46 \mathrm{~T}(2 \mathrm{H}, \mathrm{J}=7.2$ Гц, аром.), $7.61 \mathrm{~T}$ (1H, J = 7.1 Гц, аром.), 7.67 т (1H, J = 7.3 Гц, піридин), 7.76 д (1Н, J = 8.1 Гц, аром.), 7.77с (1Н, аром.), 7.86 д $(2 \mathrm{H}, \mathrm{J}=7.5$ Гц, аром.), $7.96 \mathrm{c}(1 \mathrm{H}, \mathrm{CH}), 8.16 \mathrm{~T}$ $(1 \mathrm{H}, \mathrm{J}=7.4$ Гц, піридин), 8.73 д $(1 \mathrm{H}, \mathrm{J}=3.8$ Гц, піридин).

5-(Z)-(4-Хлоробензиліден)-2-бензоїліміно-3-(2піридил)-4-тіазолідинон (9). Вихід - 56 \%, Т.пл. 242-244 ${ }^{\circ} \mathrm{C}$ (ЕtOH). Знайдено, \%: N - 10,20, S - 7,70. $\mathrm{C}_{22} \mathrm{H}_{14} \mathrm{CIN}_{3} \mathrm{O}_{2} \mathrm{~S}$. Вирахувано, \% N - 10,01, S -7,64.

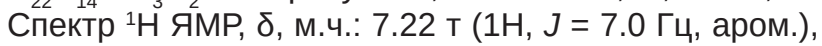
7.47 т (2H, J =7.2 Гц, аром.), 7.64-7.72 м (4Н, аром., піридин), 7.83 д (2H, J = 8.4 Гц, аром.), 7.86 д $(2 \mathrm{H}, \mathrm{J}=7.3$ Гц, аром.), $8.02 \mathrm{~s}(1 \mathrm{H}, \mathrm{CH}), 8.18 \mathrm{~T}$ $(1 \mathrm{H}, \mathrm{J}=7.4$ Гц, піридин), 8.74 д (1Н, J = 4.2 Гц, піридин).

ISSN 2312-0967. Pharmaceutical review. 2017. № 1 
Синтез біологічно активних сполук

Synthesis of biologically active compounds

5-(Z)-(4-Бромобензиліден)-2-бензоїліміно-3-(2піридил)-4-тіазолідинон (10). Вихід - 28 \%, Т.пл. 171-173 ${ }^{\circ} \mathrm{C}$ (EtOH). Знайдено, \%: N - 9,20, S - 7,00. $\mathrm{C}_{22} \mathrm{H}_{14} \mathrm{BrN}_{3} \mathrm{O}_{2} \mathrm{~S}$. Вирахувано, \% N - 9,05, S - 6,91. Спектр ${ }^{1} \mathrm{H}$ ЯМР, $\delta$, м.4.: 7.05 т (1Н, J = 7.4 Гц, аром.), 7.47 т (2H, J =7.2 Гц, аром.), 7.40-7.46 м (3Н, аром., піридин), 7.54 д (2H, J = 8.0 Гц, аром.), 7.72-7.80 м (4H, аром.), 7.84 с (1H, CH), 8.10 т (1Н, J = 7.4 Гц, піридин), 8.37 д (1Н, J = 3.6 Гц, піридин).

Загальна методика синтезу 5-ариліден-3-(2піридил)-2,4-тіазолідиндіонів (11-15).

Суміш 0,003 моль відповідного 5-ариліден-2бензоїліміно-3-(2-піридил)-4-тіазолідинону в суміші 5 мл оцтової кислоти та 2 мл концентрованої хлоридної кислоти кип'ятять із зворотним холодильником протягом 4 год. Розчиник відганяють у вакуумі, а утворений твердий залишок обробляють водою та етанолом. Утворений продукт перекристалізовують з етанолу.

5-(Z)-(4-Ізопропілбензиліден)-3-(2-піридил)-2,4тіазолідиндіон (11). Вихід - 56 \%, Т.пл. - 120-122 ${ }^{\circ} \mathrm{C}$ (EtOH). Знайдено, \%: N - 8,80, S - 9,90. $\mathrm{C}_{18} \mathrm{H}_{16} \mathrm{~N}_{2} \mathrm{O}_{2} \mathrm{~S}$. Вирахувано, \% N - 8,64, S - 9,88. Спектр ${ }^{1} \mathrm{H}$ ЯМР, $\delta$, м.ч.: 1.20 д $(1 \mathrm{H}, \mathrm{J}=6.9$ Гц, $\mathrm{CH}), 2.90$ м $\left(6 \mathrm{H}, 2{ }^{*} \mathrm{CH}_{3}\right)$, 7.30 т (1Н, J = 7.9 Гц, піридин), 7.40 д (1Н, J = 7.8 Гц, піридин), 7.52 д (2H, J = 8.9 Гц, аром.), 7.70 д $(2 \mathrm{H}, \mathrm{J}=8.0$ Гц, аром.), $7.90 \mathrm{c}(1 \mathrm{H}, \mathrm{CH}), 8.06$ т (1Н, J =7,4 Гц, піридин), 8.62 д ( $1 \mathrm{H}, \mathrm{J}=4.2$ Гц, піридин).

5-(Z)-(4-Метоксибензиліден)-3-(2-піридил)-2,4тіазолідиндіон (12). Вихід - $54 \%$, Т.пл. - 148-150 ${ }^{\circ} \mathrm{C}$ (EtOH). Знайдено, \%: N - 8,80, S - 10,40. $\mathrm{C}_{16} \mathrm{H}_{12} \mathrm{~N}_{2} \mathrm{O}_{3} \mathrm{~S}$. Вирахувано, \% N - 8,97, S - 10,27. Спектр ${ }^{1} \mathrm{H}$ ЯМР, $\delta$, м.4.: 3.85 с (3H, $\left.\mathrm{OCH}_{3}\right), 7.15$ д $(2 \mathrm{H}, \mathrm{J}=8.4$ Гц, аром.), 7.67 д (2H, J = 8.4 Гц , аром.), 7.59 т (1Н, J = 6.7 Гц, піридин), 7.62 д (1Н, J =7.6 Гц, піридин), 7.98 с (1Н, СН), 8.08 т (1Н, J = 7.4 Гц, піридин), 8.67 д (1Н, J = 5.0 Гц, піридин).
5-(Z)-(3,4-Диметоксибензиліден)-3-(2-піридил)2,4-тіазолідиндіон (13). Вихід - 61 \%, Т.пл. - 132$134{ }^{\circ} \mathrm{C}$ (EtOH). Знайдено, \%: N - 8,30, S - 9,50. $\mathrm{C}_{17} \mathrm{H}_{14} \mathrm{~N}_{2} \mathrm{O}_{4} \mathrm{~S}$. Вирахувано, \% N - 8,18, S - 9,37. Спектр ${ }^{1} \mathrm{H}$ ЯMР, $\delta$, м.4.: 3.82 с $\left(3 \mathrm{H}, \mathrm{OCH}_{3}\right), 3.84 \mathrm{c}\left(3 \mathrm{H}, \mathrm{OCH}_{3}\right)$, 7.18 с (1Н, аром.), 7.29 д (1Н, J = 7.2 Гц, піридин), 7.61 м (3Н, аром., піридин), $7.98 \mathrm{c}(1 \mathrm{H}, \mathrm{CH}), 8.09 \mathrm{~T}$ $(1 \mathrm{H}, \mathrm{J}=7.8$ Гц, піридин), 8.66 д $(1 \mathrm{H}, \mathrm{J}=4.2$ Гц, піридин).

5-(Z)-(4-Хлоробензиліден)-3-(2-піридил)-2,4тіазолідиндіон (14). Вихід - $75 \%$, Т.пл. $-170-172{ }^{\circ} \mathrm{C}$ (EtOH). Знайдено, \%: N-9,00, S-10,20. $\mathrm{C}_{15} \mathrm{H}_{9} \mathrm{CIN}_{2} \mathrm{O}_{2} \mathrm{~S}$. Вирахувано, \% N - 8,84, S - 10,12. Спектр ${ }^{1} \mathrm{H}$ ЯМР, $\delta$, м.ч.: 7.40 т $(1 \mathrm{H}, \mathrm{J}=7.4$ Гц, піридин), 7.62 д $(1 \mathrm{H}$, $\mathrm{J}=5.2$ Гц, піридин), 7.70 д (2H, J = 8.4 Гц, аром.), 7.83 д $(2 \mathrm{H}, J=8.4$ Гц, аром.), $7.94 \mathrm{~s}(1 \mathrm{H}, \mathrm{CH}), 8.16 \mathrm{~T}(1 \mathrm{H}$, $\mathrm{J}=7.4$ Гц, піридин), 8.70 д (1Н, J = 4.7 Гц, піридин).

5-(Z)-(4-Бромобензиліден)-3-(2-піридил)-2,4тіазолідиндіон (15). Вихід - 79 \%, Т.пл. - 246-248 ${ }^{\circ} \mathrm{C}$ (EtOH). Знайдено, \%: N-7,80, S-8,70. C ${ }_{15} \mathrm{H}_{9} \mathrm{BrN}_{2} \mathrm{O} 2 \mathrm{~S}$. Вирахувано, \% N - 7,76, S - 8,88. Спектр ${ }^{1} \mathrm{H}$ ЯМР, $\delta$, м.ч.: 7.42 т $(1 \mathrm{H}, J=7.4$ Гц, піридин), 7.50 д $(1 \mathrm{H}$, $\mathrm{J}=5.0$ Гц, піридин), 7.54 д (2H, J = 8.0 Гц, аром.), 7.65 д (2H, J = 8.0 Гц, аром.), 7.90 с $(1 \mathrm{H}, \mathrm{CH}), 8.12 \mathrm{~T}$ (1Н, J = 7.4 Гц, піридин), 8.30 д (1Н, J = 4.0 Гц, піридин).

Висновки. 1. Шляхом поєднання модифрікації реакцій [2+3]-циклоконленсації, Кньовенагеля та кислотного гідролізу одержано серії 5-ариліден-3піридил-4-тіазолідинонів роданінового, псевдотіогідантоїнового та тіазолідиндіонового рядів.

2. На основі спектрів ПМР підтверджено стереоселективне проходження реакції Кньовенагеля 3 утворенням 5-(Z)-ариліден-4-тіазолідинонів.

3. Проводиться фрармакологічний скринінг нових похідних 4-тіазолідинону.

\section{СИНТЕЗ З-ПИРИДИЛЗАМЕЩЕННЫХ 4-ТИАЗОЛИДИНОНОВ КАК ПОТЕНЦИАЛЬНЫХ БИОЛОГИЧЕСКИ АКТИВНЫХ СОЕДИНЕНИЙ}

\section{М. Н. Войтыра, Р. Б. Лесык}

Львовский национальный медицинский университет имени Данила Галицкого madzia_ustka@interia.pl,dr_r_lesyk@org.lviv.net

Цель работы. Осуществить синтез 3-пиридилзамещенных 5-арилиден-4-тиазолидинонов как потенциальных биологически активних соединений.

Материалы и методы. Исходные реагенты синтезированные по известным методикам с коммерчески доступных реактивов. ${ }^{1} \mathrm{H}$ ЯМР спектры снимались на приборе Varian Gemini $400 \mathrm{MHz}$. Температуры плавления определяли на приборе ВÜСНI B-545.

Результаты и обсуждение. Получены 3-пиридилзамещенные 5-арилиден-2-тиоксо-4-тиазолидиноны на основе метода Гольмберга и реакции Кневенагеля. Для синтеза структурно близких 3-(2-пиридил)-2,4-тиазолидиндионов предложен двухэтапный подход, который базируется на однореакторной («one-pot») трехкомпонентной реакции 1-бензоил-3-(пиридин-2-ил)-2-тиомочевине, монохлоруксусной кислоте и ароматического альдегида с образованием 5-арилиден-2-бензоилимино-3-(2-пиридил)-4-тиазолидинонов, которые в условиях кислотного гидролиза с високими выходами з високими виходами образуют целевые продукты. Структура синтезированных соединений подтверджена методом спектроскопии ПМР.

ISSN 2312-0967. Фармацевтичний часопис. 2017. № 1 
Синтез біологічно активних сполук

Synthesis of biologically active compounds

Выводы. Синтезирована серия новых 3-пиридилзамещенных производных роданина, тиазолидиндиона и псевдотиогидантоина. Стереоселективность реакции Кневенагеля и образование 5-(Z)-арилиден-4-тиазолидинонов подтверждена данными спектров ПМР.

Ключевые слова: синтез; 4-тиазолидиноны; [2+3]-циклоконденсация; реакция Кневенагеля; спектральные характеристики.

\section{SYNTHESIS OF 3-PYRIDYL SUBSTITUTED 4- THIAZOLIDINONES AS POTENTIAL BIOLOGICALLY ACTIVE COMPOUNDS}

\section{N. Wojtyra, R. B. Lesyk}

Danylo Halytsky Lviv National Medical University

madzia_ustka@interia.pl,dr_r_lesyk@org.lviv.net

The aim of the work. The synthesis of 3-pyridylsubstituted 5-arylidene-4-thiazolidinones as potential biologically active compounds.

Materials and Methods. All starting materials were purchased from commercial sources and used without purification. The ${ }^{1} \mathrm{H}$ NMR spectra were recorded on a Varian Gemini 400-MHz instrument. Melting points are uncorrected and were measured in open capillary tubes on a BÜCHI B-545 melting point apparatus.

Results and Discussion. Novel 3-pyridylsubstituted 5-arylidene-2-thioxo-4-thiazolidinones were synthesized using Holmberg method and Knoevenagel reaction. For the synthesis of structurally similar 3-(2-pyridyl)-2.4-thiazolidinediones two-stage approach were proposed. This approach is based on «one-pot» three-component reaction of 1-benzoyl-3(pyridine-2-yl)-2-thiourea, chloroacetic acid and aromatic aldehyde yielding 5-arylidene-2-benzoylimino-3-(2-pyridyl)-4thiazolidinones which via acid hydrolysis in high yields form the target products. The structure of synthesized compounds was confirmed by NMR spectroscopy.

Conclusions. A series of novel 3-pyridylsubstituted rhodanine, thiazolidinedione and psudothiohydantoine derivatives were synthesized. The ${ }^{1} \mathrm{H}$ NMR spectra futures confirmed stereoselectivity of Knoevenagel reaction and obtaining of 5-(Z)arylidene-4-thiazolidinones.

Key words: synthesis; 4-thiazolidinone; [2+3]-cyclocondensation; Knoevenagel reaction; spectral characteristics.

\section{Список літератури}

1. Fortin S. Advances in the development of hybrid anticancer drugs / S. Fortin, G. Berube // Expert Opin. Drug Discov. - 2013. - Vol. 8. - P. 1547-1577.

2. Havrylyuk Dmytro. Synthetic approaches, structure activity relationship and biological applications for pharmacologically attractive pyrazole / pyrazoline-thiazolidine-based hybrids / Dmytro Havrylyuk, Olexandra Roman, Roman Lesyk // Eur. J. Med. Chem. - 2016. - Vol. 113. - P. 145-166. 3. Lesyk R. B. 4-Thiazolidones: Centenarian history, current status and perspectives for modern organic and medicinal chemistry / R. B. Lesyk, B. S. Zimenkovsky // Curr. Org. Chem. - 2004. - Vol. 8. - P. 1547-1577.

4. Synthetic and Evaluation of Some Pyridine containing Thiazolidinones / S. D. Firke, B. M. Firake, R. Y. Chaudhari [et al.] // Asian J. Research Chem. - 2009. - Vol. 2, №2. P. 157-161.

5. Hassan H. Y. Synthesis and Antimicrobial Activity of Pyridines Bearing Thiazolines and Thiazolidinone Moietes / H. Y. Hassan, N. A. El-Koussi, Z. S. Farghaly // Chem. Pharm. Bull. - 1998. - Vol. 46, №5. - P. 863-866.

6. Chaubey A. Pyridine a versatile nucleus in pharmaceutical field / A. Chaubey, S. N. Pandeya // Asian J. Pharm. Clin. Res. - 2011. - Vol.4, №4. - P. 5-8.
7. Synthesis and antiproliferative effect of novel 4-thiazolidinone-, pyridine- and piperazine based conjugates on human leukemic cells / K. S. S. Kumar, A. Hanumappa, M. Hegde [et al.] // Eur. J. Med. Chem. - 2014. - Vol. 81. - P. 341-349.

8. 5-Ene-4-thizolidinones induce apoptosis in mammalian leukemia cells / J. Senkiv, N. Finiuk, D. Kaminskyy [et al.] // Eur. J. Med. Chem. - 2016. - Vol. 117. - P. 33-46.

9. Havrylyuk D. Ya. Synthesis of pyrazoline-thiazolidinone hybrids with trypanocidal activity / D. Ya. Havrylyuk, B. S. Zimenkovsky, O. Karpenko [et al.] // Eur. J. Med. Chem. - 2014. - Vol. 85. - P. 245-254.

10. 2-Pyridyl thiazoles as novel anti-Trypanosoma cruzi agents: structural design, synthesis and pharmacological evaluation / M. V. Cardoso, L. R. de Siqueira, E. B. da Silva [et al.] // Eur. J. Med. Chem. - 2014. - Vol. 86. - P. 48-59. 11. Synthesis and anticancer activity evaluation of 4-thiazolidinones containing benzothiazole moiety / D. Havrylyuk, L. Mosula, B. Zimenkovsky [et al.] // Eur. J. Med. Chem. 2010. - Vol. 45, №11. - P. 5012-5021.

12. Rout M. K. 2- $\beta$-Naphthylimino-4-thiazolidone and its Derivatives / M. K. Rout, G. N. Mahapatra // J. Am. Chem. Soc. - 1955. - Vol. 77, №9. - P. 2427-2428.

ISSN 2312-0967. Pharmaceutical review. 2017. № 1 
Синтез біологічно активних сполук

Synthesis of biologically active compounds

\section{References}

1. Fortin S, Berube G. Advances in the development of hybrid anticancer drugs. Expert Opin Drug Discov. 2013;8: 1547-77.

2. Havrylyuk D, Roman O, Lesyk R. Synthetic approaches, structure activity relationship and biological applications for pharmacologically attractive pyrazole/pyrazoline-thiazolidine-based hybrids. European Journal of Medicinal Chemistry. 2016;113: 145-66.

3. Lesyk RB, Zimenkovsky BS. 4-Thiazolidones: Centenarian history, current status and perspectives for modern organic and medicinal chemistry. Curr Org Chem. 2004;8: 1547-77.

4. Firke SD, Firake BM, Chaudhari RY, Patil VR. Synthetic and Evaluation of Some Pyridine containing Thiazolidinones. Asian J Research Chem 2009;2(2): 157-61.

5. Hassan HY, El-Koussi NA, Farghaly ZS. Synthesis and Antimicrobial Activity of Pyridines Bearing Thiazolines and Thiazolidinone Moietes. Chem Pharm Bull. 1998;46(5): 863-6.

6. Chaubey A, Pandeya SN. Pyridine a versatile nucleus in pharmaceutical field. Asian. J Pharm Clin Res. 2011;4(4): 5-8. 7. Kumar KSS, Hanumappa A, Hegde M, Narasimhamurthy $\mathrm{KH}$, Raghavan SC, Rangappa KS. Synthesis and anti- proliferative effect of novel 4-thiazolidinone-, pyridine- and piperazine based conjugates on human leukemic cells. Eur J Med Chem. 2014;81: 341-9.

8. Senkiv J, Finiuk N, Kaminskyy D, Havrylyuk D, Wojtyra M, Kril I, et al. 5-Ene-4-thizolidinones induce apoptosis in mammalian leukemia cells. Eur J Med Chem. 2016;117: 33-46.

9. Havrylyuk DYa, Zimenkovsky BS, Karpenko O, Grellier P, Lesyk RB. Synthesis of pyrazoline-thiazolidinone hybrids with trypanocidal activity. Eur J Med Chem. 2014;85: 24554.

10. Cardoso MV, de Siqueira LR, da Silva EB, Costa LB, Hernandes MZ, Rabello MM, et al. 2-Pyridyl thiazoles as novel anti-Trypanosoma cruzi agents: structural design, synthesis and pharmacological evaluation. Eur J Med Chem. 2014;86: 48-59.

11. Havrylyuk D, Mosula L, Zimenkovsky B, Vasylenko O, Gzella A, Lesyk R. Synthesis and anticancer activity evaluation of 4-thiazolidinones containing benzothiazole moiety. Eur J Med Chem. 2010;45(11): 5012-21.

12. Rout MK, Mahapatra GN 2- $\beta$-Naphthylimino-4thiazolidone and its Derivatives. $\mathrm{J} A m$ Chem Soc. 1955;77(9): 2427-8. 